\title{
FAST-TRACKING THE LITERACY DEVELOPMENT IN STREET CHILDREN: A READING AND WRITING PROJECT FOR STREET CHILDREN
}

Rénee Nathanson

Stellenbosch University

The Education for All Global Monitoring Report 2007 revealed that seventy-seven million children of primary school age are not enrolled in schools. Furthermore, despite continued reforms at the primary level, too many school-going children drop out early or do not reach minimal learning standards. This paper describes a collaborative project between researchers at Stellenbosch University and Georgia State University to raise the literacy levels of street children in a unique school in the Western Cape. Given that traditional scientific models have not been successful in raising literacy levels in South African schools, the project implemented a flexible teaching framework in which instructional decisions were based on careful observation of individual children's reading and writing behaviours (Clay, 2005; McEneaney, Lose \& Schwartz, 2006). It was assumed that the insights gained from working with children who had no prior literacy experiences would benefit other lowperforming schools. The literacy levels of grade one children in the street-school were assessed at intervals over a one-year period. The results showed that the children were making good progress and that the rate of literacy learning accelerated. Finding ways to integrate scholarship, practice and community development could build capacity for continuous improvements in literacy standards.

\section{INTRODUCTION AND BACKGROUND}

According to the Education for All Global Monitoring Report seventy-seven million children of primary school age are not enrolled in schools. More than three quarters of them are in Africa and Asia (United Nations Education, Science and Cultural Organisation, 2007). Furthermore, despite continued reforms at the primary level, too many school-going children drop out early or do not reach minimal learning standards (Organisation for Economic Cooperation and Development, 2008; Progress in International Reading Literacy Study, 2006; Western Cape Education Department, 2006). Against this background, an aid organization started a small school in the Western Cape with the unique mission of addressing the educational and social needs of street children ${ }^{1}$.

In 2005, the school approached the Language Focus Group at Stellenbosch University to assist them in developing a literacy intervention for street children, because the children attending the school were not making adequate progress through traditional methods of instruction. This paper briefly contrasts some major differences between traditional approaches to literacy and the theory of literacy learning that guided the intervention. Then it 
explains the research design and methodology before concluding with a discussion of the outcomes of the intervention.

\section{THEORETICAL BASE}

Our theoretical approach shared many of the principles underlying instruction in Reading Recovery ${ }^{2}$, which make it possible to accelerate the progress of the lowest achieving children (Fountas \& Pinnell, 1996). These principles differ significantly from traditional assumptions (Clay, 1991b:56-57). Four of these differences are discussed next.

First, the theoretical base underpinning the intervention emphasised a cognitive processing approach to reading and writing, rather than traditional additive approaches that focus on the number of letters or words a child can identify (Fountas \& Pinnell, 1996; Duncan, 1999; Clay, 2001). According to Clay's (2002) cognitive processing theory, strategic readers 'work' actively to gain meaning from print by cross-checking and integrating multiple sources of information, such as syntactic, semantic, visual and phonological information. In doing so, they develop a rich cognitive network that they can use to read independently (Clay \& Cazden, 1992:115-116). In contrast to this, low-progress readers tend to use a narrow range of strategies (e.g. inventing from memory, guessing words, sounding out words) that limit their opportunities to decipher more difficult texts. For these reasons, Cazden describes high progress readers as 'cue users' and low progress readers as 'oral language guessers' (Clay \& Cazden, 1992:116).

To encourage readers to become 'cue users' rather than 'oral language guessers', the streetschool intervention focused strongly on reading and writing continuous text (as opposed to learning isolated items of knowledge). Orality was developed through meaningful interactions and discussion about whole texts, rather than through direct teaching (Nathanson, 2008). We agree with viewpoint that there is a reciprocal relationship between learning to speak and learning to read (Shefelbine, 1998; Scientific Learning Corporation, 2008). Cunningham and Stanovich (1998) found that extensive reading is linked to superior performance on measures of general knowledge, vocabulary, reading comprehension and verbal fluency. Likewise, Shefelbine (1998:1) confirms that the amount of reading children do significantly affects the development of general knowledge and overall verbal ability. He argues that learning to read the unique, decontextualised language of books is a long-term process, which is similar to learning a language. It can only be acquired by 'using and living it as a way of life' (Shefelbine, 1998:1). Snow (1991:7) maintains that 'only the more decontextualised language skills have been found to relate to literacy'. Overall, these arguments suggest that an understanding of the reciprocal relationship between reading, writing and orality should lead to more effective teaching interactions and more economical use of teaching time.

Second, in contrast to traditional approaches that stress reading before writing, we share Robinson's (1973) standpoint that writing is of critical importance for learning to read. Through rigorous statistical analysis, Robinson (1973) demonstrated that, in the early stages of learning to read, a child's writing vocabulary was the main predictor of early reading progress. One of the reasons writing is such a critical factor in learning to read is because the process of writing 'forces' children to attend to details in print (Clay, 2001:56). Adams (1990) points out that relying too much on context to identify unknown words during reading can hinder the development of orthographic knowledge, which is important for fluent reading. Writing, on the other hand, helps children develop essential orthographic knowledge because it 'forces' them to treat language as an object of analysis in its own right (Cazden, 1992:61). 
By attending analytically to the oral language they already use, children also learn to use phoneme-to-letter correspondences (Cazden, 1992). Thus, teaching reading and writing concurrently enables children to make links between speaking, reading and writing and provides teachers with valuable practical information to improve instruction (Clay, 2002:15). These beliefs conflict with traditional approaches that separate reading and writing in theory and practice (Clay, 1991b:56). Clay (2001:18) found that teachers who neglect early writing severely limit children's opportunities to learn, thereby 'contributing to slower progress overall, at a time when it is most important to learn quickly'.

Third, the approach adopted in the street-school intervention calls into question the 'readiness' approach that views children as either ready or not ready for literacy instruction. In contrast to 'readiness' theory, the literacy intervention attempts to match instruction to each child's 'zone of proximal development', that is, a child's level of potential development as determined through problem solving under the guidance of more capable adults (Vygotsky, 1978; Ballantyne, 2008:1). We share Ballantyne (2008) and Clay and Cazden's (1992) view that learning which is directed at the child's zone of potential development leads to the creation of new forms of cognitive activity. Learning therefore depends a great deal on the kinds of opportunities teachers provide to further the development of well-elaborated cognitive networks in children (Lyons, 2003; Pinnell \& Fountas, 2007).

A principle that can be drawn from the notion of 'the zone of proximal development' is that 'good learning' is that which is in advance of development (Ballantyne, 2008:4). When applied to reading, this principle states that out of the early reading and writing experiences young children create a network of competencies, which lead to subsequent independent literacy learning. Clay (1991a) refers to this as a self-extending system because it helps a good reader become better as a result of his own efforts. These generic competencies are constructed by children as they interact with many kinds of information that are available in continuous texts. As children read books or write texts they form hypotheses about the rules of language and how to use them to put messages together in meaningful ways (McCarrier, Fountas \& Pinnell, 1996; Calkins, 2006). Therefore to accelerate learning, teachers should help children construct effective self-extending systems by focusing on children's strategic responses to texts, such as using many sources of information in texts simultaneously, predicting, drawing on prior knowledge, monitoring their reading and self-correcting (Rumelhart \& McClelland, 1986; Goodman \& Goodman, 1998). Delaying access to reading and writing deprives children of the sources of information that can help them build selfextending systems. Thus, our work was based on the generic theory that learning is a constructive process, that is, learning generates further learning (Clay, 2001).

Lastly, the concept of the zone of proximal development leads logically to the idea that teachers need an observation tool that will enable them to understand the internal course of each child's cognitive development. Such observation should reveal to teachers whether instruction is stimulating the development of new cognitive networks in individual children (Clay, 2002; Ballantyne, 2008). Given that development is not static and that it varies from child to child, instructional decisions based on systematic observation should be flexible and responsive to individual children's current level of literacy processing (McEneaney, Lose \& Schwartz, 2006:122). By revealing what a child's strengths and needs are, observation stops teachers from wasting precious learning time on things that children can already do (Clay, 1991b:71). This kind of close and systematic observation is very different to traditional tests that deal mainly with the actual developmental level of children (Ballantyne, 2008; Clay, 2002). 
To summarise, in contrast to traditional, single theory approaches, which emphasise isolated items (e.g. letter-sound correspondences) our theoretical orientation emphasised a cognitive processing approach (Fountas \& Pinnell, 1996; Clay 2001). The latter is grounded in a complex theory that assumes that success in learning to read and write depends on different cognitive systems working in parallel rather than acting alone (Rumelhart \& McClelland, 1986; Clay, 2001:237). It encourages a constructive approach to literacy learning, because it assumes that the child is constructing interacting competencies in reading and writing in ways that 'extend both the searching and linking processes as well as the item knowledge repertoires' (Clay, 2001:224). From a developmental perspective, the model emphasises the concept of dynamic development and aims to enable emergent readers to develop a strategic base for the complex literacy processing that they will engage in several years later.

Having clarified the theoretical base that guided the street-school intervention, the next section describes the research design and methodology, including the planning and implementation phases of the literacy intervention.

\section{TYPE OF RESEARCH AND DESIGN CLASSIFICATION}

The study may most aptly be described as a 'hybrid variation' because it fits some, but not necessarily all of the criteria in some of the standard, methodological packages (Leedy, 1993:139). We used the criterion of appropriateness to allow us to combine elements of different methods (e.g. qualitative and quantitative) and different types of case studies (e.g. many to single-subject case studies, descriptive case studies) in a flexible design, which suited the data being studied as well as our research interests and objectives, namely, to implement an early literacy intervention aimed at improving the literacy achievements of street children (Huysamen, 1994; De Vos, 2005).

\section{DATA COLLECTION INSTRUMENTS}

We used the observational methodology outlined in An Observation Survey of Early Literacy Achievement (Clay, 2002) to gain data of children's progress on the following tasks: Letter Identification, Word Reading, Writing Vocabulary, Hearing and Recording Sounds in Words (Dictation), and Running Records. These observation tasks provided us with 'evidence of learning on repeated measurements of tasks like the one the child is actually undertaking in the classroom'. The authenticity of the tasks gave them credibility with teachers (Clay, 2002:3). Clay's unusual observational methodology also enabled us to obtain unique data of changes in each child's literacy processing behaviours (qualitative data), which provided us with invaluable information for individualising and improving instruction (Fountas and Pinnell, 1996; Clay, 2002)

To provide a check of children's knowledge of important basic concepts such as the front of a book, where to start reading and directionality, we included Davidson's (1991) Concepts about Print (CAP) survey in our observation battery. Thus, six observation tasks were used to assess children's literacy learning in the intervention. 


\section{PARTICIPANTS, SCOPE AND TRAINING}

As mentioned earlier, we were approached in 2005 to help raise the literacy standards in a unique school for street children. The school served sixty children in grade one to seven. The staff consisted of three foundation phase teachers (females), two intermediate phase teachers (1 male, 1 female), a secretary and a headmistress. All staff members were Afrikaansspeakers. The teachers followed a skills-based, phonics-based approach to literacy instruction.

Given the nature of the task, we contacted Dr Duncan, Director of Reading Recovery ${ }^{\circledR}$ at Georgia State University, to help us design an appropriate research intervention. We argued that the street-school was the ideal receptive environment to introduce approaches to literacy based on principles used internationally in Reading Recovery ${ }^{\circledR}$. Reading Recovery ${ }^{\circledR}$ is an early intervention programme with a strong theoretical and research base and with proven effectiveness in raising the reading achievements of the lowest performing students (Institute of Education Sciences, 2007:1).

After obtaining some initial data on reading levels in the street-school, we decided to limit the intervention to the grade one classroom to provide maximum support and to ensure that the children received the earliest possible start to literacy learning. With sponsorship from the Rotary club of Gordon's Bay, we sent Adele, the grade one teacher to America in 2005 to attend intensive training under the mentorship of Dr Duncan at Georgia State University. As part of her training, Adele observed Reading Recovery ${ }^{\circledR}$ lessons and visited mainstream classrooms where teachers used instructional practices that were consistent with the theoretical rationales underpinning Reading Recovery ${ }^{\circledR}$ (Fountas \& Pinnell, 1996). Then, having seen alternative approaches to phonics-based instruction in action, Adele returned to South Africa to implement a pilot programme in her grade one classroom in January 2006.

\section{RESEARCH SAMPLE}

There were thirteen children (seven girls and six boys) in Adele's grade one classroom. Two children were Xhosa-speaking. The others spoke Afrikaans. Since Afrikaans was the medium of instruction, the intervention targeted the progress children were making in learning to read and write in Afrikaans. The study should be regarded as exploratory because the sample was small and it was limited to the children attending a non-traditional school.

\section{IMPLEMENTATION IN THE STREET-SCHOOL IN GRADE ONE}

To be able to implement and support the underlying theoretical base outlined thus far, a number of significant changes were required in the grade one classroom. These included changes in the physical environment, in routines, activities, materials and in the quality of teacher-learner interactions (Iversen \& Reeder, 1998; Calkins, 2001). Calkins (2001) contends that it is important for a teacher to keep her instructional framework fairly consistent and predictable to prevent confusion amidst the complexities of change. We therefore structured literacy lessons around a flexible framework that incorporated the following: Systematic Observation, Reading Aloud, Shared Reading, Guided Reading, Independent Reading and Interactive Writing. 


\section{SYSTEMATIC OBSERVATIONS WERE THE STARTING POINT}

Because we view assessment as an integral part of teaching, one fundamental change we made in the grade one classroom was to use systematic observation of learning as a means to inform instruction. We agree with Clay (2001) that one of the key reasons for the slow rate of literacy learning is that many children are not receiving the kind of help they need to learn at a faster pace. We began the intervention in January 2006 by using Clay's observational methodology to gather benchmark data of each learner in grade one. Thereafter, we monitored the children's progress on each of the six observation tasks at frequent intervals. Differences between the benchmark and exit scores of each task were used as indicators of progress (see Figure 1). Data obtained from the observation tasks also provided us with continuous feedback for helping Adele improve her interactions with children during reading and writing sessions. As mentioned earlier, although we did not teach oral language skills directly, all the aforementioned approaches rely on oral language as basis and they all focus on building links between oral and written language (Fountas \& Pinnell, 1996:41). The next section provides a brief, research-based description that emphasises the value of each instructional approach used in the intervention.

\section{READING ALOUD}

Adams (1990:86-87) is convinced that 'the most important activity for building the knowledge and skills required for reading is that of reading to children'. Likewise, Weaver (1994:97) maintains that learning to read begins when children listen to stories. Being read to enables children to construct semantic maps for understanding what it means to be literate individuals. Reading to children also demonstrates reading for a purpose, provides an adult demonstration of phrased, fluent reading, develops a sense of story, develops knowledge of how different texts are structured and demonstrates the pleasure and enjoyment of reading. For these reasons, reading to the street children, whose pre-school experiences with books were minimal, was clearly an important activity.

\section{SHARED READING}

Davidson (1991:8) defines Shared Reading as a story time activity that 'involves the teacher with a whole class...sitting close together while they share in the reading of appealing rhymes, songs, poems and stories'. It is evident that Shared Reading in the classroom is based on the emotional intimacy and enjoyment that preschool children experience during bedtime storybook reading. To conduct a Shared Reading lesson a teacher uses Big Books or any text with enlarged print so that children can see clearly and join in the reading. During Shared Reading lessons teachers explicitly demonstrate effective reading strategies such as word-byword matching, predicting and meaningful reading. The values of Shared Reading include social support from the group, opportunities to participate and behave like readers, and creating a body of known texts that children can draw on for independent reading and writing. Another important consideration for using it in the intervention was that it gives lowachieving children access to higher order strategies that they would not be exposed to in guided reading groups where children of similar reading levels are grouped together. 


\section{GUIDED READING}

Hornsby (2000) refers to Guided Reading as the 'heart' of any good literacy program. Fountas and Pinnell (1996:2) define Guided Reading as 'a context in which a teacher supports each reader's development of effective strategies for processing novel texts at increasingly challenging levels of difficulty'. It is clear from these definitions that there are a number of essentials in successful guided reading. First, teachers' interactions should be theory-driven and anchored in observation of children as they read. Second, in order to group children with similar reading competencies and to move readers to new groups based on reading progress, teachers need to monitor each reader's reading level. Third, each child in a guided reading group should have his own copy of a book. Hence, it is necessary to have multiple copies of each book available for effective group teaching. To ensure that children develop a 'sense of story', the books should be interesting, 'whole' stories that can be read in one session (Hornsby, 2000). Reading 'whole texts' enables children to develop comprehension strategies for predicting, confirming and self correcting (Fountas \& Pinnell, 1996; Weaver, 1998). Fourth, guided reading texts should be levelled, because it is essential to match children to books. Books should also be organised on a continuum of difficulty so that children can be promoted to books at higher levels. To foster strategic reading children should have access to a number of different texts of similar difficulty levels. This prevents children from memorising books and develops flexible reading systems (Clay, 1991a). It is clear that Guided Reading cannot take place successfully in the absence of systematic observation procedures, theory-driven instruction and a wide range and variety of sets of levelled texts. For these reasons, careful consideration was given to the selection of observational procedures and books for the guided reading purposes in the intervention.

\section{INDEPENDENT READING}

Calkins (2001:9) observes that if educators want children to learn to 'compose richly literate lives' in which they take ownership of reading, they need daily opportunities to read books that 'they choose for themselves for their own purposes and pleasures'. Numerous researchers have pointed out that many children do not become avid readers because they do not have access to books (Hornsby, 2000:46; Calkins, 2001:27; Diller 2003:35). Thus, one of the most feasible options for developing literacy is the provision of a rich supply of high-interest books in the classrooms.

To foster children's independent reading and to gradually lessen teacher control, we used Hornsby's (2000:23) Continuum of Support model. This model requires teachers to gradually release responsibility for reading to the children. For example, during reading aloud, the teacher provides maximum support; during Shared and Guided Reading the teacher and children take joint responsibility for the reading task, and during independent reading children practise reading strategies and interpret texts on their own. In our literacy intervention, children often read on their own or to partners (we found that children reading to their teddy bears worked well. In fact, teddy workshops instil the concept of reading to...).

\section{INTERACTIVE WRITING}

From the first day of the intervention, the grade one children were provided with abundant opportunities to write. The instructional model used for writing followed the same gradual 
release of responsibility model that was used in reading, that is, the teacher first acted as scribe (writing for) of messages composed by the children from their knowledge of oral language. During interactive writing sessions Adele 'shared the pen' with the children, a technique which involves children in the writing process (McCarrier, Fountas \& Pinnell, 1996). Adele also conducted guided writing sessions with small groups in which children engaged in writing a variety of texts. During these sessions Adele guided the process and provided instruction though mini-lessons. During independent writing, children wrote their own messages and stories. Frequently, these messages demonstrated that the street children were taking ownership of their roles as readers and writers. For example, one of the children wrote: 'Now that I can read and write, I love my school'. Messages such as these demonstrated that the intervention had a positive impact on children's self-esteem and on their perceptions of school. Clay's (2002:27) found that it takes a child only three to four months at school to define himself as 'no good' at reading and writing. In a similar vein, Dahl and Freppon's (1998) research indicated that children who were averse to reading and writing in the early grades, were unlikely to continue in school.

\section{RESEARCH RESULTS AND DISCUSSION}

Having been run for a year in the first grade in the street-school, the intervention ended in November 2006. The results of repeated observations on five tasks taken during the year are discussed next.

\section{COMPARISON OF AVERAGES ON FIVE OBSERVATION TASKS}

Figure 1 compares the averages of thirteen children in Adele's grade one classroom on the following tasks:

Letter Identification (maximum score: 54 )

Word Test (maximum score: 15)

Writing Vocabulary (open ended)

Hearing and Recording Sounds in Words (Dictation) (maximum score: 38 )

Concepts About Print (CAPS) (maximum score: 18)

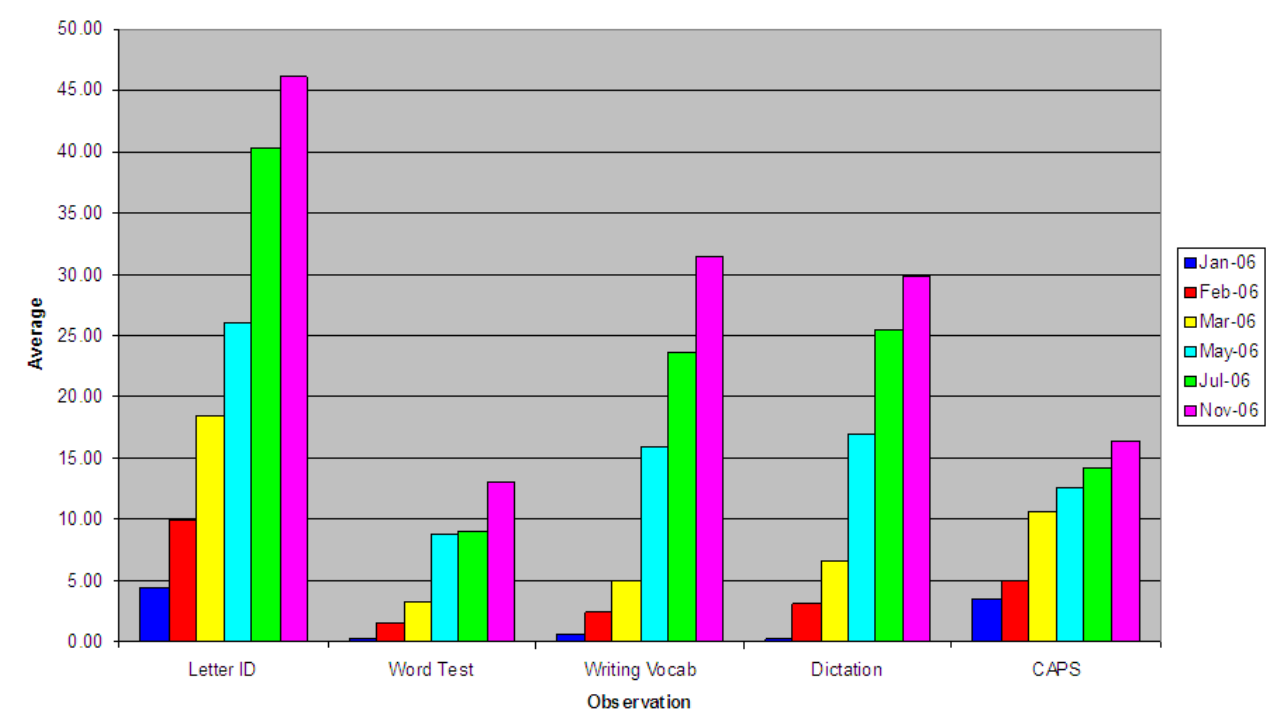

Figure 1: Grade one: Comparison of averages on five observation tasks 
Each section in this graph represents a different observation (assessment task). Each task has a different maximum score (see above). Each observation was conducted at intervals from January to November. Each colour bar represents a different month.

The graph illustrates that in each of the assessments, the scores improved from close to zero to near maximum. This indicates a dramatic overall improvement.

When considered jointly with the results of the running records (see Figure 2), it is clear from the progress made in each observation task that the street children were developing and extending their competencies in a number of different aspects of literacy. This indicated that the children were developing self-extending systems that would enable them to become independent readers and writers. In contrast to this, Clay (2002) found that instruction that emphasises one source of information above another places children at a severe disadvantage.

\section{RECORDS OF READING CONTINUOUS TEXTS}

Each month running records were used to assess how the grade ones were reading continuous texts. The graph in Figure 3 plots the progress of the grade one children through a series of early reading books that were levelled along a gradient of difficulty from easy to most difficult.

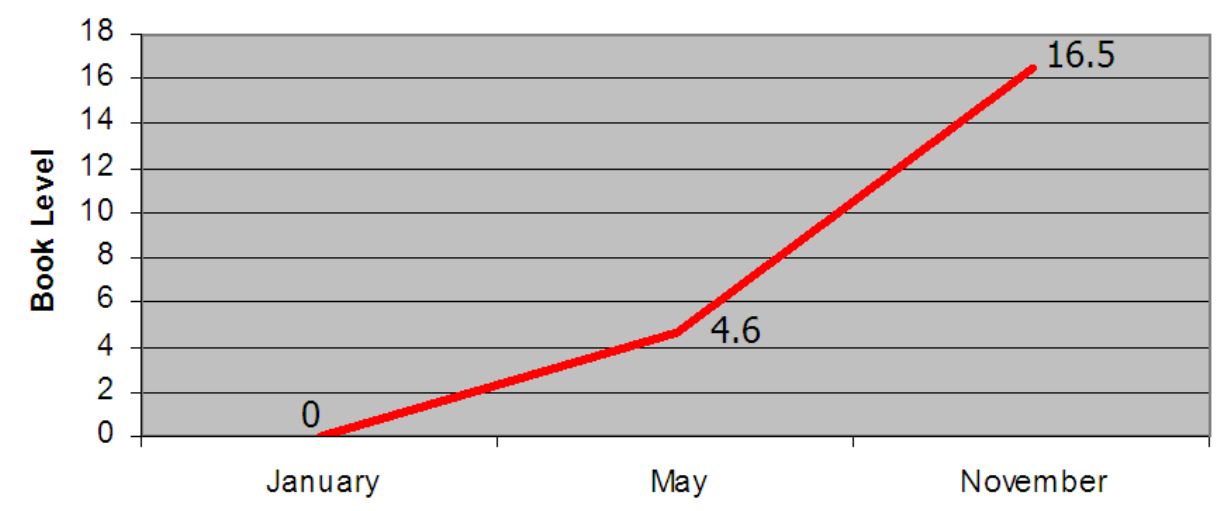

\section{Figure 2: Average book levels}

Reading scores improved from zero to 16.5 over the year, which meant that the children were reading at grade level at the end of the year. This was in sharp contrast to the previous year's grade ones whose average reading level at the end of grade one was 2.5.

The theory behind the literacy intervention underscores that children have to learn to integrate several levels of language and check several sources of information against each other to derive meaningful messages when reading continuous texts. The progress made by the grade one street children illustrates that they were able to 'put together' their knowledge of letters, sounds and words in reading continuous texts (Clay, 2002:49).

\section{COMPARISON BETWEEN GRADES ONE AND GRADE TWO ON SIX OBSERVATION TASKS}

Although the literacy intervention was only implemented in grade one in the street-school, the grade two teacher asked us to assess the progress of her children before the June school 
holiday. There were sixteen children in the grade two class. Given that conducting the observation tasks is time-consuming, we agreed to do a once-off assessment of the grade twos at the end of May. We assessed sixteen grade two children on the following five observation tasks: Letter Identification, Word Test, Writing Vocabulary, Dictation and Concepts About Print (see Figure 3). We assessed fourteen grade two children using running records of text reading (two children were absent when the running records were taken).

The results of assessments provided us with an interesting set of data for comparing the midyear progress of children in grade one with the progress of children in grade two. In May 2006, the average reading score for the grade two children was 3.6. The average reading score for the grade one children was 4.6 (see Figure 2). Figure 3 shows the comparison between grade one and grade two on the five other observation tasks.

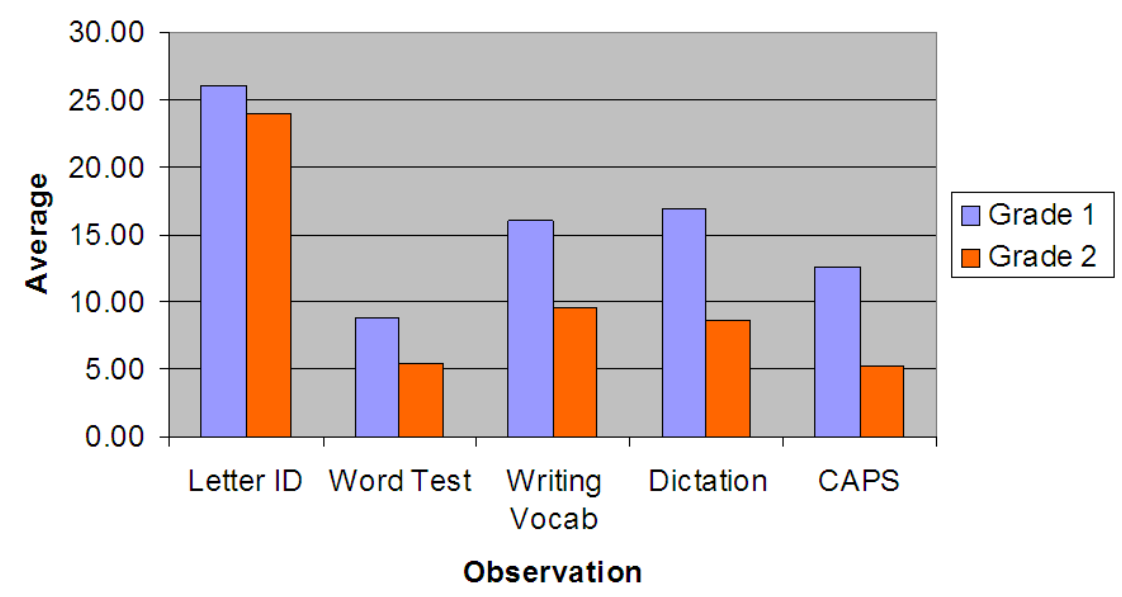

Figure 3: Comparison between grades one and grade two on five observation tasks

This graph shows that the grade ones on the project have better scores on the observation tasks than the grade twos who were not part of the literacy intervention. In addition, it was clear from their low reading scores that the grade two children were not able to apply their knowledge of letters, words and sounds in reading.

\section{CONCLUSION}

Clay (2001:256) makes the point that if we know how to ensure that students will learn to read in the early grades, 'we have an ethical and perhaps legal responsibility to see that they do so'. By targeting street children in the literacy intervention we hoped to show that it is possible to accelerate the progress of low-performing children. Even though we realise that a small amount of data from an exploratory study cannot be generalised across settings, we nevertheless agree with Clay (2001:3) and De Vos (2005:395) that small research studies can collectively contribute to the existing body of knowledge in the field. By linking the findings from the street-school intervention with the research and theory base in early literacy, we hope to make significant contributions in the field of literacy that can bring about life-saving changes for the most vulnerable children (Fountas \& Pinnell, 1996; Clay, 2002; Calkins, 2006). 
The literacy intervention has since expanded to another mainstream school and has stimulated further research. We have used the experience we gained in working with street children to design a teacher-development model that uses practising teachers from our project schools to model best practice to other teachers. We have also set up demonstration classrooms where university students and practising teachers can 'see' how theory works in practice. In 2009 we will begin a research project in a mainstream school to increase the amount of reading children do in school and at home. In this way, we can integrate scholarship, practice and community development.

\footnotetext{
${ }^{1}$ The term 'street children' refers to children for whom the street, rather than their families, has become their real home. Not all street children are homeless or without families, but they do not have protection or supervision from responsible adults (Human Rights Watch Publications, 2007).

${ }^{2}$ Reading Recovery® is an intervention programme for individual children for whom supplementary teaching is essential.
}

\section{REFERENCES}

ADAMS, M. 1990. Beginning to read: Thinking and learning about print. Massachusetts: MIT Press.

BALLANTYNE, P. 2008. Zone of proximal development: A new approach. [Online]. Available: www.comnet.ca/ pballan/Vygotsky [2008, March 17].

CALKINS, L. 2001. The art of teaching reading. New York: Longman.

CALKINS, L. 2006. The art of teaching writing. Portsmouth: Heinemann.

CLAY, M. 1991a. Becoming literate: The construction of inner control. Auckland: Heinemann.

CLAY, M. 1991b. Reading Recovery surprises. In Deford, D., Lyons, C. \& Pinnell, G. (eds.). Bridges to literacy: Learning from Reading Recovery. Portsmouth: Heinemann. 55-74.

CLAY, M. 2001. Change over time in children's literacy development. Auckland: Heinemann.

CLAY, M. 2002. An observation survey of early literacy achievement ( $2^{\text {nd }}$ edition). Auckland: Heinemann.

CLAY, M. 2005. Literacy lessons designed for individuals. Part two. Auckland: Heinemann.

CLAY, M \& CAZDEN, C. 1992. A Vygtoskian interpretation of Reading Recovery. In Cazden, C, (ed.). Whole language plus: Essays on literacy in the United States and New Zealand. Columbia: Teachers College Press. 114-135.

CAZDEN, C. 1992. Play with language and metalinguisitic awareness. In Cazden, C, (ed.). Whole language plus: Essays on literacy in the United States and New Zealand. Columbia: Teachers College Press. 59-75.

CUNNINGHAM, A \& STANOVICH, K. 1998. What reading does for the mind. American Educator, 22(1\&2):8-15.

DAHL, K. \& FREPPON, P. 1998. A comparison of innercity children's interpretations of reading and writing instruction in the early grades in skills based and whole language classrooms. In Weaver, C. (ed.). Reconsidering a balanced approach to reading. Urbana, Illinois: National Council of Teachers. 271-320.

DAVIDSON, A. 1991. Concepts about print test. Auckland: Shortland Publications. 
DE VOS, A. 2005. Qualitative data analysis and interpretation. In de Vos, A., Strydom, H., Fouche, C. \& Delport, C. (eds.). Research at grass roots for the social sciences and human service profession ( $3^{\text {rd }}$ edition). Pretoria: Van Schaik.

DILLER, D. 2003. Literacy workstations. Portland: Stenhouse Publishers.

DUNCAN, S. 1999. Reading Recovery ${ }^{\circledR}$ national training guide: Introduction of an observation survey of early literacy achievement. Reading Recovery®: Georgia State University.

FOUNTAS, I. \& PINNELL, G. 1996. Guided reading. Portsmouth: Heinemann.

GOODMAN, Y. \& GOODMAN, K. 1998. To err is human: Learning about language processes by analyzing miscues. In Weaver, C. (ed.). Reconsidering a balanced approach to reading. Urbana, Illinois: National Council of Teachers. 101-126.

HORNSBY, D. 2000. A closer look at guided reading. Armadale: Eleanor Curtain.

HUMAN RIGHTS WATCH PUBLICATION. 2007. Human Rights Watch: Street children. [Online]. Available: http://www.humanrightswatch.net [2007, October 1].

HUYSAMEN, G. 1994. Methodology for the social and behavioural sciences. Halfway House: Southern Book Publishers.

INSTITUTE OF EDUCATION SCIENCES. 2007. What Works Clearinghouse Intervention Report: Reading Recovery. [Online] Available: http://ies.ed.gov/ncee/wwc/reports/beginning reading [2007, April 14]

IVERSEN, S. \& REEDER, T. 1998. Organizing for a literacy hour: Quality learning and teaching time. Auckland: Lands End Publishing Ltd.

LEEDY, P. 1993. Practical research: Planning and design. New York: Macmillan Publishing Company.

LYONS, 2003. Teaching struggling readers. Portsmouth: Heinemann.

McCARRIER, A., FOUNTAS, G. \& PINNELL, I. 1996. Interactive writing. Portsmouth: Heinemann.

McENEANY, J., LOSE, M. \& Schwartz, R. 2006. A transactional perspective on reading difficulties and response to intervention. Reading Research Quarterly, 41(1): 117-128.

NATHANSON, R. 2008. A school-based, balanced approach to early reading instruction for English additional language learners in grades one to four. Doctoral dissertation. Stellenbosch: Stellenbosch University.

ORGANISATION FOR ECONOMIC CO-OPERATION AND DEVELOPMENT. 2008. Reviews of national policies for education - SA. [Online]. Available: http://www.oecd.org [2008, November 13].

PINNELL, G \& FOUNTAS, I. 2007. The continuum of literacy learning, grades K-8. Portsmouth: Heinemann.

PROGRESS IN INTERNATIONAL LITERACY STUDY. 2006. PIRLS 2006 International report. [Online] Available: www.pirls.bc.edu/pirls2006/intl_rpt.html [2007, August 30].

ROBINSON. S. 1973. Predicting early reading progress. Master of Arts thesis. Auckland: University of Auckland. 
RUMELHART, D. \& McClELLAND, J. 1986. Parallel distributed processing. Vol. 1: Foundations. Cambridge, MA: MIT Press.

SCIENTIFIC LEARNING CORPORATION. 2008. Adding ten minutes of reading time dramatically changes levels of print exposure. [Online]. Available: www.scilearn.com/resultsreports [2008, October 21].

SHEFELBINE, J. 1998. Reading: Voluminously and voluntary. [Online]. Available: www.scholastic.com [2008, November 14].

SNOW, C. 1991. The theoretical basis for relationships between language and literacy in development. Journal of Research in Childhood Education 6(1): 5-10.

UNITED NATIONS EDUCATIONAL, SCIENTIFIC AND CULTURAL ORGANIZATION. 2007. Education for all global monitoring report. United Nations: UNESCO Publishing.

VYGOTSKY, L. 1978. Mind in society. In Cole, M., John-Steiner, V., Scribner, S. \& Souberman, E. (eds.). Cambridge: Harvard University Press.

WEAVER, C. 1994. Reading process and practice: From socio-psycholinguistics to whole language ( $2^{\text {nd }}$ Edition). Portsmouth: Heinemann.

WEAVER, C. 1998. Toward a balanced approach to reading. In Weaver, C. (ed.). Reconsidering a balanced approach to reading. U.S.A: National Council of Teachers. 11-74.

WESTERN CAPE EDUCATION DEPARTMENT. 2006. Literacy and numeracy. [Online]. Available: www.wced.wcape.gov.za/comms/press/2007/ebudget.html [2007, November 13].

\section{BIOGRAPHIC NOTE}

Rénee Nathanson is a lecturer in the Department of Curriculum Studies at Stellenbosch University. Her research interests include cognition and reading comprehension, early literacy intervention and professional development for literacy teachers. (Email: rrn@sun.ac.za) 